\title{
PEDAGÓGICA: DIÁLOGO DA LIBERTAÇÃO LATINO-AMERICANA A PARTIR DE ENRIQUE DUSSEL E PAULO FREIRE
}

\section{Ricardo Prestes Pazello}

Graduando do $3^{\circ}$ ano da Faculdade de Direito da UFPR; e-mail: ricardo2p@yahoo.com.br

RESUMO: $O$ presente trabalho visa promover uma análise dialógica entre os pensamentos do filósofo da libertação Enrique Dussel e do pedagogo brasileiro Paulo Freire. O escopo último é dar justamente uma panorâmica do que seria a libertação latino-americana nos termos prévios de uma pedagógica, a qual é momento ético da libertação do referido continente na perspectiva de Dussel. Exatamente por ser a pedagógica a convergência da erótica com a política, é que a mesma se apresenta como referencial para se pensar, de início, um novo período da filosofia da libertação latino-americana, qual seja, o da práxis efetiva a partir do sistema pedagógico. De Dussel podemos inferir as concepções de totalidade, exterioridade, libertação e alienação, além de seu método próprio, a analética, que superando a dialética, tem-na como parte de si; eis a ana-dia-lética. Sem esquecer, ainda, a ética da libertação, baseada na materialidade humana, a partir da alteridade, característico de dita filosofia. De Paulo Freire resgatamos toda uma idéia de pedagogia do oprimido, conforme as categorias de educação bancária e problematizadora, além da dialogicidade e da conscientização. Com referido marco teórico procuramos a saída para o sistema de opressão, sob o ponto de vista filosófico. Por fim, adentramos no campo da idéia do encobrimento da América Latina e tentamos propôr um novo lugar metodológico na diacronia e diatopia transmoderna, finalizando com uma abordagem do direito enquanto sistema pedagógico exemplar da prática dominadora.

PALAVRAS-CHAVE: Filosofia da Libertação. Pedagogia do Oprimido. Libertação Latino-Americana. Transmodernidade. Educação Dialógica. Enrique Dussel. Paulo Freire. 
Ninguém

Ninguém vai me segurar

Ninguém há de me fechar

As portas do coração

Ninguém

Ninguém vai me sujeitar A trancar no peito a minha paixão

Eu não

Eu não vou desesperar

Eu não vou renunciar

Fugir

Ninguém

Ninguém vai me acorrentar

Enquanto eu puder cantar

Enquanto eu puder sorrir

(Cordão, de Chico Buarque)

Cambia, todo cambia

Cambia, todo cambia

Pero no cambia mi amor por mas lejos que me encuentre

ni el recuerdo ni el dolor de mi pueblo y de mi gente Lo que cambió ayer tendrá que cambiar mañana así como cambio yo en esta tierra lejana

(Todo cambia, de Julio Numhauser) 


\section{PREMISSAS DA ABORDAGEM}

Desde o "achamento" do continente americano, tem-se negligenciado nossa verve cultural e, por conseguinte, toda nossa condição de sermos o que deveras somos, latino-americanos. Os esforços que, aos poucos, se vêm intentando em nosso continente ainda são pequenos diante da imensa máquina que se nos traga de contínuo, a totalidade ocidental supra-equatorial e seu sistema de opressão. Entrementes, as mais singelas tentativas de mudança do panorama que sempre foi a tônica no ocidente, partindo dos gregos e chegando à contemporaneidade capitalista, ou seja, a opressão nos mais diversificados ramos da formação social, demonstram-se como prenúncio e sincera tentativa de transformação do estado de coisas atual. Este trabalho corporifica tal constatação. Ele é fruto de uma reflexão desenvolvida no interior de um grupo de estudos, o qual se estabeleceu com o desiderato prévio de compreender o direito sob uma perspectiva crítica e que vem se aportando na filosofia desenvolvida na América Latina, no que se considera de sua autenticidade; refiro-me ao "Reinventar", que reúne acadêmicos de direito da UFPR em prol de uma visão diferenciada da (incons)ciência jurídica.

Sabendo-nos como inquietos, na busca inveterada por compreensão do que legitima a situação atual de nosso mundo e, em especial, do que se convencionou chamar de Terceiro Mundo, partimos de uma concepção anterior, no âmbito da latino-americanidade, qual seja, o entendimento de que tal legitimação não existe. É por isso que resgatamos aqui um pensamento próprio de nosso continente, com Enrique Dussel e Paulo Freire.

A perspectiva que daremos tem iminentemente um viés pedagógico. A proposta de uma Filosofia da Libertação Latino-Americana de Dussel nos permite um olhar mais acurado sobre nós mesmos e uma reflexão mais crítica sobre o "regime" de opressão ideológica, e física, que impera em nossos rincões. Paulo Freire, por seu turno, apresenta-se-nos como a práxis latino-americana a ser seguida nas trilhas de uma pedagógica nos termos da libertação.

Assim, fica evidente a tarefa tapuia (para não dizer hercúlea, como aceitação crítica da totalidade do helenismo) que é a proposição de uma saída para a exploração da América Latina, sem a incluir depois na mesma configuração, 
explorando os outros. A despeito disso, encontrar novos caminhos é assaz necessário; a libertação, nosso escopo.

\section{ENRIQUE DUSSEL, UMA FILOSOFIA DA LIBERTAÇÃO}

Tendo em vista nossas premissas, é importante ressaltar outras, como ocorre com a idéia de filosofia. Já se tornou corrente a definição de que a filosofia é uma reflexão crítica, radical e de totalidade ${ }^{1}$ sobre questões do mundo. É crítica por pôr sob crivo permanente o objeto de sua reflexão, não se o deixando acomodar na conformidade de uma dada concepção. É radical por não se contentar com a superficialidade do dado, por buscar, até, o momento do construído, inclusive enquanto dinâmica inarredável do processo filosófico, a gênese, a órbita primitiva e intencional do projetado, enfim, a raiz da problemática. Já estando, o refletido, criterizado e radicalizado, é ressaltável considerá-lo sob a premissa do total, da abrangência que possibilita a visão do todo, da totalidade; a dialética a ser usada imprescinde da totalidade, a qual se caracteriza pela concretude, reportando a idéia abstrata à esfera do parcial.

Nessa panorâmica é que podemos inferir a função que a Filosofia da Libertação tem a exercer. Muitas são as classificações que permitem lobrigar dita filosofia, sendo inclusive bastante coerente decodificá-la como um movimento polissêmico, de passos múltiplos. No entanto, é possível encontrar autênticas convergências teóricas. David Sánchez Rubio, citando Antonio Sidekum, diz que

a pesar de la heterogeneidad tendencial y de la diversidad de enfoques que la conforman, ante todo lo que las une es que son una ética de la liberación, cuyo principal fundamento estriba en la simple presencia y decidida aceptación de la alteridad. ${ }^{2}$

A partir disso, perfilhamos a idéia de que nossa incompletude filosófica é inegável. Mesmo sendo de grande aporte o já feito até hoje, nossa práxis ainda não se consagrou minimamente. De nós, a teoria ainda tem de ladrilhar o obscuro caminho de um grande processo pela libertação. Isso muito por decorrência da

\footnotetext{
${ }^{1}$ Não confundir o aspecto da totalidade da filosofia, que permite a compreensão do todo concreto, com o conceito de totalidade definido por Dussel, o qual representará um sistema que está em oposição a uma exterioridade oprimida, e que será no decorrer deste trabalho abordado.

2 SÁNCHEZ RUBIO, David. Filosofia, derecho y liberación en América Latina. Bilbao: Disclée, 1999, p. 110.
} 
condição negada da América Latina, e é por tanto que, dialeticamente, ter se chegado à consideração de nossa exclusão, uma exterioridade frente a uma totalidade de centro, apresenta-se como avanço inestimável. A filosofia desenvolvida por Dussel, nesse ponto, aproveitada é de forma bastante ávida e com remissão inesgotável. Ainda assim, pensamos que o trabalho é árduo e que o que Marx formulara em sua décima-primeira tese contra Feuerbach - "os filósofos se limitaram a interpretar o mundo diferentemente, cabe transformá-lo"3 - ainda não se concretizou, por completo, entre os latino-americanos, e quiçá nem mesmo na totalidade do norte global, o que, porém, não nos impede de buscarmos a diacrônica persecução tanto de uma interpretação que nos diga respeito, bem como uma transformação que nos permita a urgente libertação.

Segundo Euclides André Mance ${ }^{4}$, didaticamente, a Filosofia da Libertação tem uma trajetória distinguível em três momentos: o primeiro seria o período de emergência da mesma; o segundo diria respeito ao período de avaliação crítica, síntese e difusão da idéia; o terceiro, quanto aos diálogos filosóficos norte-sul. Dussel teria tido papel de destaque em todos esses momentos. Precursor junto a Assman, Kusch e Roig; tendo revisado sua sistematização, criticamente, com o livro, de 1977, Filosofia de la Liberación; e interlocutor assíduo dos diálogos norte-sul, principalmente frente ao pensamento de Apel. Dessa forma, o referido autor nos apresenta como das melhores figuras para análise que pretendemos efetuar com este trabalho.

\subsection{A anterioridade do homem}

Enrique Dussel é um filósofo da práxis, nascido em Mendoza, na Argentina de 1934. Tem uma longa história de luta pela libertação latino-americana, tendo sido, inclusive, vítima de um atentado à bomba do governo militar argentino. Manejou, certamente, um ferramental marxista, e por isso seu diálogo constante com os conceitos trazidos por essa corrente filosófica. ${ }^{5}$ Das suas principais contribuições

\footnotetext{
${ }^{3}$ MARX, Karl. Teses contra Feuerbach, p. 53.

${ }^{4}$ MANCE, Euclides André. Uma introdução conceitual às filosofias de libertação, p. 38 e seguintes.

${ }^{5}$ Conferir OLIVEIRA, Rosa Maria Rodrigues de. Ética da Libertação em Enrique Dussel, p. 89-90.
} 
teóricas, podemos dar destaque à ética que se evidencia como sendo um apanágio opcional de todos os excluídos, no concernente a uma filosofia da libertação. Em tal escolha ética vislumbra-se, desde logo, a anterioridade antropológica, um momento de consideração prévia do homem enquanto ser-de-vida, como um pressuposto a ser considerado frente a sua dignidade e de acordo com uma consciente escolha teórico-prática.

Para promover suas análises a partir de tal anterioridade antropológica, Dussel se utiliza de dois conceitos fundamentais: o da alteridade e o da exterioridade.

A alteridade, o ponto comum das filosofias da libertação, caracteriza-se pela "passagem diacrônica, desde o ouvir a palavra do outro até a adequada interpretação"6 do mesmo, de acordo com uma ética pressuposta, pré-adotada, aportada no homem. Dussel revela tal sugestão com base no ouvir-o-outro, não apenas subsumindo-o em sua totalidade, mas compreendendo-o após uma temporalidade diacrônica, em que o assumido resgata o escutado e expressa-se na palavra da aceitação alterada (de alteridade).

Possuindo como próprio o fundamento ontológico com base no qual o outro, na diacronia da palavra reveladora, pronunciou sua palavra, agora, no futuro do passado passado, no presente, pode-se referir aquela palavra recordada no horizonte atual e vigente alcançado pela práxis libertadora e a partir do outro revelante, provocante. ${ }^{7}$

É importante notar aqui a ênfase à concepção diacrônica de tempo, que é um tempo mais ligado à leitura do mundo e de escolha da forma de encará-lo, ou seja, de libertá-lo em conjunto, muito na linha daquilo que Paulo Freire vai chamar de leitura da "palavramundo", na qual o alfabetizando, já adulto, lê, em primeiro lugar, o seu mundo, para depois ler a palavra escrita e a partir de então fazer uma leitura, releitura e tresleitura contínua do mundo em mutuidade com a palavra do papel. ${ }^{8}$ Também é resgatável a concepção tríbia de tempo que o brasileiro Gilberto Freyre arrolou como grande característico do pensamento de origem ibero-americana, tendo como idéia o tempo em suas divisões básicas não cindíveis, assim, um único instante, passado-presente-futuro, sem o molde do pensar

\footnotetext{
${ }^{6}$ DUSSEL, Enrique. Método para uma filosofia da libertação, p. 208.

7 DUSSEL, Idem, ibidem.

${ }^{8}$ Ver texto FREIRE, Paulo. A importância do ato de ler, primeiro ensaio.
} 
nórdico do tempo-dinheiro, imediatismo que estanca o tempo, e o faz vetor de opressão permanente. ${ }^{9}$

Outro conceito fundante da obra dusseliana é o de exterioridade. Parte-se, aqui, de Marx, em sua idéia do "trabalho vivo do trabalhador". ${ }^{10} \mathrm{Na}$ releitura do filósofo argentino, vai se chegar à idéia de um sistema opressor, o que até hoje se pode ver, como índice de totalidade que, por decorrência, também se demonstra como opressora, por, justamente, negar o outro em sua diferença, no que não lhe é reconhecível em si mesmo a partir de si mesmo. É o contraponto ideológico da totalidade, politicamente a Europa e a América Anglo-Saxã, a exterioridade, politicamente a América Latina e o Terceiro Mundo. Todo sistema de totalidade gera uma exterioridade e se tal sistema for fulcrado na opressão e na competição desleal aí é que tal exterioridade se verificará com maior vigor. Deve-se, então, "compreender a exterioridade como transcendentalidade interior ao sistema". ${ }^{11} \mathrm{O}$ excluído não está fora do sistema, mas de sua capacidade autônoma frente ao mesmo, por isso é que meras políticas de inclusão de nada servem, pois, em última análise, perpetuam a mesma opressividade dos que se encontram perfeitamente incluídos. Dessarte, o excluído está dentro do sistema, sendo sua exterioridade, transcendentalmente falando.

\subsection{A ana-dia-lética}

Todo o ideário dusseliano é perpassado, como visto, a partir do pressuposto antropológico, da afirmação do homem, seja em sua alteridade, seja em sua exterioridade, com vistas a superar a opressão. No plano do método, por sua vez, arrebata-se o conjunto de idéias anteriormente estabelecido, concatenando-se uma saída para a tradicional concepção do assunto. Falamos, aqui, do momento analético da ontologia latino-americana, a qual supera a mera totalidade dialética. A analética é a verdadeira dialética, aquela que toma como inferido o homem, enquanto outro, em seu conteúdo; o antropológico constitui o método.

\footnotetext{
${ }^{9}$ Aqui é interessante a abordagem do livro FREYRE, Gilberto. Além do apenas moderno.

${ }^{10}$ LUDWIG, C. L. A alternatividade jurídica na perspectiva da libertação, p. 111.

${ }^{11}$ DUSSEL, E. Filosofia da Libertação na América Latina, p. 53.
} 
A analética vem para suprir o que a dialética da totalidade não dá conta; aliás, se é da totalidade, gera uma exterioridade, que não a nega, mas que a interpela provocativamente, escutando a voz clamorosa do outro combalido pelos ouvidos moucos da totalidade. Além de isso, é um ato de doação revolucionária, é dar-se à práxis com o oprimido. É uma crítica, enfim, da totalidade.

O momento analético é a afirmação da exterioridade: não é somente negação da negação do sistema desde a afirmação da totalidade. É superação da totalidade, mas não só como atualidade do que está em potência no sistema. É superação da totalidade desde a transcendentalidade interna ou da exterioridade, o que nunca esteve dentro. ${ }^{12}$

É, assim, afirmação de possibilidade do novo, do mais-alto-que o velho, detectado e assumido dialeticamente, como o é o filho para o casal saudável, na erótica ética.

Dessa forma, lobrigamos no método o caminho ana-dia-lético. É a anterioridade antropológica assumida como fundamento da forma, deslocando-se e conjugando-se a uma dialética positiva e verdadeira. Vai para além da totalidade dialética, não é um simples raciocínio formal (bem usado por Aristóteles, Tomás Hobes ou Hegel), antes uma opção "embutida" no método, pelo desenrolar das várias graduações éticas, como a econômica, a erótica e a política. ${ }^{13}$ Ainda assim, é um inter-relacionamento metodológico. É a concepção diatópica do existir da totalidade-exterioridade e a escolha ética anterior.

\section{3. Ética da Libertação: a crítica formal}

Propõe-nos Dussel uma arquitetônica para a adoção concreta de toda essa formulação de libertação, desde a alteridade até a analética. Incorre, então, em forte postura para definir os momentos éticos, os quais auxiliam na configuração da assunção da latino-americanidade como propulsora do movimento que pretende revolucionar a visão da sociedade. São seis os seus momentos: material, formal e da factibilidade, articulando os fundamentos; e crítica material, crítica formal e

\footnotetext{
12 DUSSEL, E. Filosofia da Libertação na América Latina, p. 164-165.

${ }^{13}$ Conferir DUSSEL, E. Método para uma filosofia da libertação, p. 197.
} 
factibilidade crítica, como a tessitura cabal da Filosofia da Libertação. ${ }^{14}$ Ater-nosemos, entretanto, no quinto momento ético, qual seja, o da crítica formal, já que o mesmo diz respeito mais expressamente à lição pedagógica de Paulo Freire, combinada com o desenvolvido pelo próprio Dussel.

De forma geral, os momentos éticos se caracterizam pela passagem do critério ao princípio, vale dizer, do ser ao dever-ser. Para, mais especificamente, o momento da crítica formal se concretizar, é preciso que leve a cabo o disposto na crítica material, numa ligação indissolúvel. Pauta-se pela validade anti-hegemônica da comunidade das vítimas. No critério, tem-se o ser intersubjetivo de validade. Para algo ser válido na comunidade crítica e materialmente posta, faz-se necessário que haja espaço para a intersubjetividade, para a forma que dê base à mesma. Todos participam, então, de uma nova comunidade. Sai-se de um consenso para um dissenso, adentrando-se num novo consenso.

Já no princípio, é uma necessidade que o discurso seja comunitário, respeitando as diferenças inextricáveis das pessoas, buscando-se, porém, o novo consenso. O que antes era descrição agora é normatividade. Toda crítica deve ser registrada de acordo com a forma intersubjetiva da comunidade de vítimas.

Primeiramente, cabe a denúncia da injusta exclusão. É um momento de consciência do estar fora dos círculos decisórios e no qual se deve partir para uma crítica do estabelecido. Aqui, tem grande relevo a idéia de Paulo Freire, com sua conscientização educadora, nos moldes de uma verdadeira politização que permita ao homem sua libertação. É o lugar do ceticismo crítico mediante a totalidade coeva. Eis, então, o aspecto negativo do princípio referido.

Seu teor positivo, por seu turno, encontra-se no anúncio de alternativas críticas que tornem factíveis a real participação e transformação social. Estamos, aqui, muito próximos da democracia participativa, direta. Assim, enxergam-se suas duas grandes tarefas, quais sejam, a explicação crítica da negatividade e a exortação pela "utopia" possível. ${ }^{15}$

De tudo, fica que os momentos da Ética da Libertação seguem, razoavelmente, o mesmo trajeto que é o da passagem de enunciados descritivos para enunciados normativos, do ser para o dever-ser, do critério para o princípio.

\footnotetext{
14 LUDWIG, C. L. Da Ética à Filosofia Política Crítica na Transmodernidade, p. 288.
} 
Também, é importante notar que a ênfase dada ao quinto momento ético permitenos chegar ao ponto que se quer no presente trabalho: a análise da pedagógica conforme Dussel e Freire.

\subsection{A pedagógica dusseliana}

A Filosofia da Libertação parte de alguns níveis de reflexão, os quais, em certa medida, já pudemos mostrar anteriormente. Os conceitos de totalidade, exterioridade, libertação e alienação devem ser, agora, repensados dentro de uma nova abordagem. É a abordagem ética, desenvolvida em quatro momentos metafísicos - política, erótica, pedagógica e antifetichismo ${ }^{16}$ - dos quais nos interessa mais especificamente o momento da pedagógica.

É importante frisar uma das primeiras ressalvas feitas por Dusse/ no capítulo em que fala mais especificamente sobre a pedagógica, dentro de seu livro Para uma ética da libertação latino-americana, qual seja, o fato de não se dever confundir a pedagógica com pedagogia. A despeito de querermos abordar o pensamento de Paulo Freire, notadamente um pedagogo, sua pedagogia não se restringe a "uma ciência do ensinamento ou aprendizagem", como classifica Dussel o contraponto da pedagógica, sendo esta última "a parte da filosofia que pensa a relação face-a-face do pai-filho, mestre-discípulo, médico-psicólogo-doente, filósofo-não-filósofo, políticocidadão, etc." ${ }^{17}$

A pedagógica é uma convergência dos momentos erótico e político. Um se caracteriza por ter como fulcro a relação familiar, pode-se dizer, a relação homemmulher, o que gerará a partir de si o filho, o novo. O outro é o momento em que se encontra a relação Estado e cultura popular, é quando o filho se torna cidadão, é quando se constitui, alienadamente ou não, o motor da sociedade. Assim, numa interessante análise, o Estado, o varão, na pedagógica primeira, qual seja, a do lar, é o pai; a cultura popular, a mulher, a mãe. "A criança que nasce no lar é educada para fazer parte da comunidade política; e a criança que nasce numa cultura, cresce

${ }^{15}$ LUDWIG, C. L. Da Ética à Filosofia Política Crítica na Transmodernidade, p. 312 e seguintes.

${ }^{16}$ Conferir DUSSEL, E. Filosofia da Libertação na América Latina, p. 73 e seguintes. Ver também OLIVEIRA, Rosa Maria Rodrigues de. Ética da Libertação em Enrique Dussel, p. 108, que, ao citar Sánchez Rubio, enumera ainda o nível econômico como integrante de tal relação ética.

17 DUSSEL, E. Para uma ética da libertação latino-americana: III - erótica e pedagógica, p. 153. 
para formar um lar". ${ }^{18}$ Aqui, a pedagógica não é só questão de educação, mas também ideológica e cultural.

Por ser justamente a ponte e o cruzamento entre a erótica e a política, a pedagógica pode ser visualizada em dois sistemas, os quais se qualificam ou como sistema pedagógico erótico, de acordo com a tradição popular, sob o manto da classe social e familiar, ou sistema pedagógico político, partindo também do mesmo item social, porém transcendendo-o, por possuir um aparato institucional, como se verifica na escolaridade oficial ou nos meios de comunicação.

Forma-se, então, uma exterioridade, o novo, que é representado pelo filho, o qual, muito provavelmente, irá contestar o velho, edipicamente, já que esse velho lhe tolhe a criação, quando muito reconhecendo-o como igual, meramente. É exterioridade porque é negado em sua novidade e por isso vem para matar o "pai" opressor, o Estado.

O filho, o procriado pelos pais (o prius) é o que chega mais longe porque é mais jovem. Existe então uma diacronia (uma temporalidade não coetânea ou contemporânea) que é muito diferente da sincronia da erótica ou da política, e que torna ambas possíveis. A descontinuidade da temporalidade pedagógica é essencialmente diacrônica por que consiste, justamente, na transmissão por transubstancialização - como diz Levinas - do legado humano às novas gerações: a juventude. ${ }^{19}$

Portanto, a cultura é transmitida pelos sistemas pedagógicos, e se é opressiva - como de fato é - tende a ser contestada, exatamente por aqueles que estão em condições para contestá-la, ou seja, os estudantes, já que não foram de todo castrados em suas inovações.

Quando a pedagogia de Rousseau prospera no ventre de um continente que não é o seu e nem teria porque o ser, ocorre um grande aborto cultural; morre-se nas tripas da sociedade. O Emílio é a pedagogia burguesa, construído com base numa estética própria e numa moral arraigadamente diferente da nossa.

Somos o colonizado, o padronizado sobre marcos distantes de nós. Nossa educação nos ensina mais sobre a Independência das Treze Colônias ou sobre a Revolução Francesa que sobre a história de nosso continente, nossos ancestrais que regaram com seu sangue estas terras em que "tudo dá".

${ }^{18}$ DUSSEL, E. Filosofia da Libertação na América Latina, p. 93. 
Entendemos por cultura imperial ou do centro aquela que domina na ordem vigente. É a refinada cultura das elites européias, norte-americanas e russas. Esta é a cultura com a qual se pretende medir todo outro grau cultural. A Gioconda mede todo outro quadro; a Quinta sinfonia de Beethoven classifica toda outra música; Notre Dame é o protótipo de toda igreja. Além disso, esta cultura tem os meios de comunicação em suas mãos. ${ }^{20}$

A pedagógica dusseliana, então, parte, como a pedagogia do oprimido freireana, da relação humana, "se desenvolve essencialmente na bipolaridade palavra-ouvido, interpretação-escuta, acolhimento da Alteridade para servir o Outro como outro". ${ }^{21}$ Destarte,

se, na verdade, o sonho que nos anima é democrático e solidário, não é falando aos outros, de cima para baixo, sobretudo, como se fôssemos os portadores da verdade a ser transmitida aos demais, que aprendemos a escutar, mas é escutando que aprendemos a falar com eles. 22

O esforço é o de uma entrega sincera ao outro, rejeitado no que é diferente, no filho assassinado pelo pai-Estado. A analética, seu método, parte da anterioridade antropológica e mais, de sua concretude, não um mero argumento formal. Ainda, o exterior é visto positivamente, não se restringindo à idéia de negar a negação.

Entrementes, emoldura-se um projeto de libertação pedagógica, uma práxis revolucionária. É uma programação baseada na conscientização, que em Paulo Freire toma ares da mais irrefragável politização. ${ }^{23}$

Com Dussel concordamos, após se exsurgido todo o propósito de libertação, que "da cultura revolucionária libertadora surgirá uma nova cultura mundial, alternativa, muito mais rica do que a atual cultura imperial". ${ }^{24} \mathrm{E}$ é nessa linha que abordaremos o pensamento de Paulo Freire para tornar mais concreta a idéia que, em Dussel, ganha contornos filosóficos formidáveis.

19 DUSSEL, E. Para uma ética da libertação latino-americana: III - erótica e pedagógica, p. 187.

${ }^{20}$ DUSSEL, E. Filosofia da Libertação na América Latina, p. 98.

21 DUSSEL, E. Para uma ética da libertação latino-americana: III - erótica e pedagógica, p. 191.

22 FREIRE, P. Pedagogia da Autonomia, p. 127.

${ }^{23}$ Vide prefácio ao livro Pedagogia do Oprimido, de autoria de Ernani Maria Fiori, um texto de 1967, intitulado Aprender a dizer a sua palavra.

24 DUSSEL, E. Filosofia da Libertação na América Latina, p. 102. 


\section{PAULO FREIRE, UMA PEDAGOGIA DO OPRIMIDO}

Durante muito tempo se costumou mencionar a existência de uma educação do colonizador, contra-face de um sistema educativo nacional, autêntico. Autenticidade, aliás, que Dussel chamaria, na esfera da cultura latino-americana, como nevralgia do ser autóctone de nosso continente. Paulo Freire, também, serviu de base para o ensejo de tal idéia. No entanto, tal concepção, contextualizadamente, não se assentou como se poderia pensar. Em um muito interessante artigo, Vanilda Paiva vai nos trazer o atraente fato de se ter restrições quanto à ontologia dessa educação do colonizador, já que pareceria ser o contraponto a uma educação construída nos moldes da burguesia nacional. Pareceria, então, que, ao invés de querermos uma pedagogia do colonizador, quiséssemos uma que fosse montada dentro dos próprios princípios da opressão nacional-burguesa. Sob esta ótica interpretativa poderíamos entender que, em última análise e grosso modo, o Freire de Educação e Atualidade Brasileira (1959) e Educação como Prática da Liberdade (1965) ainda estaria comprometido com a ideologia burguesa nacional, só se esboçando como verdadeiramente revolucionário, já com bom ferramental socialista, com a Pedagogia do Oprimido (1970). Assim, a referida autora nos interessa por partir da idéia de que necessitamos, ainda, de uma teoria do movimento operário como meio de emancipação prática dos trabalhadores e que precisa encontrar a sua pedagogia: uma pedagogia que seja capaz de contribuir para transformar as formas pré-políticas de consciência de classe em ações conscientes de classe. ${ }^{25}$

Mesmo que tais ressalvas sejam muito importantes de serem consideradas, entendemos que o próprio Paulo Freire, e a autora não o nega, já nos apresenta subsídios para uma práxis pedagógica que se apresente como palpável no processo de libertação popular latino-americana.

Nascido em 1921, na cidade do Recife, Paulo Freire costumava partir de sua família para encontrar a gênese de sua dialogia. Educador, formado em direito, dedicara-se a estudos filosóficos e trabalhara no Estado, no período anterior ao do golpe militar de 1964. Com este ocorrido, é preso por 70 dias, tendo sido rotulado

\footnotetext{
25 PAIVA, Vanilda. Do "problema nacional” às classes sociais, p. 13.
} 
como subversivo e traidor da pátria, indo para o exílio no Chile. ${ }^{26}$ Viria a trabalhar também como educador auxiliar dos governos luso-africanos, após o processo de sua descolonização. Consagra-se com o livro Pedagogia do Oprimido, tornando-se este libelo da educação que vise a libertação cultural dos educandos.

\subsection{Categorias centrais}

A obra de Freire é marcada pela presença de algumas categorias que the são bastante peculiares e que conferem a seu pensamento grande incisividade. A crítica deve sempre estar presente no processo e é por isso que categorias como opressão, educação bancária e problematizadora, dialogicidade, conscientização, temas geradores e situações-limite merecem um apreço especial em todo esse contexto. Vamos a elas.

\subsubsection{Contradição opressor-oprimido}

A teoria freireana, como se pode perceber do título de seu livro mais conhecido, parte da constatação de que há uma opressão e que esta não é mero devaneio filosófico, ela é real. Leva, irrefreavelmente, a um lutar contra, por parte de quem é oprimido, em oposição a quem oprime. "Os oprimidos, ao buscarem recuperar sua humanidade, que é uma forma de criá-la, não se sentem idealistamente opressores, nem se tornam, de fato, opressores dos opressores, mas restauradores da humanidade de ambos". ${ }^{27}$

Transforma-se, então, numa relação que deve ser superada. No entanto, tal superação lobriga-se em toda a sua arduidade, já que os próprios oprimidos tornamse hospedeiros da opressão, sendo necessária a sua expurgação. Marca-se, também, pelo medo da liberdade, item o qual leva a dois caminhos, em essência, quais sejam, o de conduzir o oprimido a igualmente oprimir ou descorçoá-lo e mantê-

${ }^{26}$ Conferir FREIRE, P. Conscientização, em especial a primeira parte, um relato (auto)biográfico do pedagogo brasileiro.

${ }^{27}$ FREIRE, P. Pedagogia do Oprimido, p. 30. 
lo na opressão inafastável. É, enfim, a visualização de um grande dilema: "querem ser, mas temem ser". ${ }^{28}$

Por tudo isso, a libertação é uma grande dor, equivalente à dor do parto, já que gerará o homem novo, superada contradição opressor-oprimido. Nesse âmbito, a pedagogia do oprimido tem de ser uma pedagogia do homem, não se desconsiderando nenhuma faticidade engendrante das mais diversas e complexas relações humanas. O educador, dessarte, tem de agir na práxis, e para tal precisa ser educado, não lhe sendo suficiente o mero contato distanciado com aqueles aos quais se destina sua tarefa.

A opressão nada mais é que se sentir dono do outro; ser dono significa possuir alguma coisa; assim, o homem é tido como coisa. Reifica-se-o, e daí passa a lutar pela sobrevivência, passando ao largo da vivência. É uma situação de controle, controle para que o dominado não se humanize, não se liberte. Assim, evidencia-se de fundamental importância o momento em que os opressores mudarem de lado e, integrando a adesão aos oprimidos, constituam a luta de libertação.

A atração pelo opressor vige, é inegável. Vencê-la é um grande desafio. Mas não o é, porém, individualmente; é coletiva a peleja. Um dos subtítulos do primeiro capítulo da Pedagogia do Oprimido nos revela bem essa idéia: Ninguém liberta ninguém, ninguém se liberta sozinho: os homens se libertam em comunhão.

Aqui a ação política equivale à cultural, a crença no oprimido não se desfaz e, por meio do diálogo, caminha-se para a revolução, a libertação na pedagógica, estendida à erótica e à política. Ganha, pois, a revolução, um iminente caráter pedagógico.

\subsubsection{Educação bancária versus educação problematizadora}

$\mathrm{Na}$ dicotomia das educações de tipo bancário e problematizador reside dos mais utilizados conceitos freireanos, muitas vezes até de maneira banalizada, mas que se constitui no grande obelisco de seu pensamento.

A concepção bancária de educação é aquela "em que a única margem de ação que se oferecesse aos educandos é a de receberem os depósitos, guardá-los

\footnotetext{
${ }^{28}$ FREIRE, P. Idem, p. 35.
} 
e arquivá-los (...); os grandes arquivados são os homens". ${ }^{29}$ Os educandos são eternos contêineres prontos para receberem todo o conhecimento, sem questionamento algum, via professor, o depósito maior, que tem por desiderato último despejar todo seu saber nas pobres cabeças vazias de seus alunos. Despreza-se, como se vê, todo o mundo provocador de saberes que compõe o entorno do educando, sua leitura passa longe de seu ensino, numa reprodução ideologicamente postada para manter a opressão característica da ordem vigente.

Frente a isso, a essa domesticação deliberada, é que se exsurge uma outra concepção de educação, qual seja, a problematizadora. Visa ela não a adaptação ao mundo, mas a sua transformação efetiva. Libertação autêntica é práxis para transformar o mundo. O quefazer do educando nesse processo não é meramente como se fosse a posição de um vaso no contexto da tela, mas antes a de um pintor que esquadrinha a nova realidade. Dota-se de uma futuridade revolucionária em que se faz a denúncia da opressão e depois se encaminha para fazer o anúncio do novo tempo, aliás, muito próximo do que teorizara Dussel. A inconclusão do homem e a consciência por ele da mesma é que o levaria à busca por ser-mais, numa solidariedade dos existentes. Então, a concepção problematizadora tem um aporte crítico que rompe com o fatalismo da prática da dominação e dirige-se à libertação. "Só existe saber na invenção, na reinvenção, impaciente, permanente, que os homens fazem no mundo, com o mundo e com os outros". ${ }^{30}$

\subsubsection{Dialogicidade e conscientização}

"O sujeito que se abre ao mundo e aos outros inaugura com seu gesto a relação dialógica em que se confirma como inquietação e curiosidade, como inconclusão em permanente movimento na História". ${ }^{31}$ Tendo em vista que a educação da libertação, e não da alienação, parte do Outro, da exterioridade transcendental de uma totalidade, não se pode olvidar que é só com o outro que se poderá galgar tal libertação, e para tanto o diálogo se faz imprescindível. Não um diálogo homogeneizador, como já ficou patente, mas um que apresente os

\footnotetext{
${ }^{29}$ FREIRE, P. Idem, p. 58.

${ }^{30}$ FREIRE, P. Idem, ibidem.

${ }^{31}$ FREIRE, P. Pedagogia da Autonomia, p. 154.
} 
dissensos e parta para novos consensos (da denúncia ao anúncio); um diálogo de conscientização.

Paulo Freire denomina a concepção problematizadora da educação como, em sinonímia, sendo a educação dialógica. Remete-nos, assim, ao quinto momento da Ética da Libertação de Dussel, à qual se assenta a crítica formal, partindo da participação da comunidade na formação dos novos consensos, ou seja, da relação dialógica que na pedagógica adquire um enlevo de dialogicidade entre o educador e o educando e todos os seus congêneres.

O diálogo na práxis freireana se imanta de uma série de predicados, já que é feita numa realidade dialógica, e não num plano ideal. Com a crueza da realidade nem sempre se consegue aplicar os belos conceitos teorizados nas escrivaninhas dos filósofos. Por isso que nos apresenta alguns pontos que não podem ser minorados: o amor, a humildade, a fé nos homens, a confiança e o pensar crítico. ${ }^{32} \mathrm{~A}$ ação dialógica da educação ainda nos aparece com outros caracteres, os quais vale a pena enumerar: a colaboração, a união, a organização e a ação cultural. ${ }^{33}$

Já a conscientização é a tentativa por desvelar o mundo de opressão que nos rodeia a todos. É a politização, que tem seu ponto inicial no diálogo. Freire destrinchou sua concepção a partir do processo de alfabetização de adultos, mas a despeito disso cremos ser aplicável em sentido lato em toda a problemática educativa latino-americana. A conscientização é a dialetização dos homens mediatizados pelo mundo, é busca contínua pela não superficialidade das coisas. Os homens se educam mutuamente e assim conscientizam-se. Não se quer dizer, com isso, que uns não possam estar em estágios mais avançados de consciência crítica, mas sim que de nada adianta tê-la sem procurar materializá-la na relação com o outro. Só faz sentido a conscientização quando socializada, em conjunto.

No diálogo de conscientização é que se sobressaem alguns instrumentos de libertação pedagógica que podemos pincelar aqui. Todo o conteúdo programático a ser abordado na prática educativa de libertação deve corresponder aos anseios e necessidades do conjunto de educandos. Veja-se, não é uma liberalidade, mas sim um esforço para fazer ter sentido tudo o que será ensinado/aprendido naquela

\footnotetext{
32 Vide FREIRE, P. Pedagogia do Oprimido, p. 79 e seguintes.

${ }^{33}$ Vide a mesma Pedagogia do Oprimido, mas agora o último item do capítulo 4.
} 
relação. Para tal, bom vetor dessa conciliação prático-teórica é a busca pelos temas geradores.

O que se pretende investigar, realmente, não são os homens, como se fossem peças anatômicas, mas o seu pensamento-linguagem referido à realidade, os níveis de sua percepção desta realidade, a sua visão do mundo, em que se encontram envolvidos seus "temas geradores". ${ }^{34}$

O conteúdo programático se organiza a partir do presente, num diálogo de proposta de problematização da existência do povo. Esse conteúdo-diálogo provém de uma realidade que inicia o processo de investigação dos temas geradores de uma sociedade. O homem, diferente do animal, é histórico; tem consciência, pode transformar sua realidade. No entanto, sói acontecer que o homem vê sua existência determinada: eis as situações-limite. É preciso ultrapassá-las e para tal, compreendê-las. Uma unidade epocal (conjunto de valores) aporta os temas geradores, os quais são o embasamento da realidade; vão do mais geral ao mais particular. Num mundo - o atual - em que vigora o irracionalismo mistificador, faz-se premente uma critica dinâmica que retire as situações-limite, como manto dos temas geradores, e, então, transforme a realidade a partir de um inédito possível e viável. ${ }^{35}$

\section{AMÉRICA LATINA ENCOBERTA, UM INOCIDENTE}

No paradigmático livro 1492: o encobrimento do Outro, Enrique Dussel nos apresenta o mito da modernidade, que fez do continente latino-americano uma grande invenção do centro da totalidade mundial opressora, a Europa. O Novo Mundo foi descoberto, posteriormente a sua invenção, e tratado como uma continuidade do que já era, o ser do norte, europeu. Somos, com o "descobrimento", reconhecidos como iguais aos que nos acharam. Se fôssemos diferentes, como deveras somos, seríamos o não-ser; se fôssemos iguais, como deveras nos fizeram crer, seríamos o ser que não somos. Assim, o descobrimento, após a invenção, é um embuste que na verdade nos encobre. Nosso descobrimento, é, em verdade, a toga que nos esconde, que nos obnubila.

\footnotetext{
${ }^{34}$ FREIRE, P. Idem, p. 88.

${ }^{35}$ Conferir FREIRE, P. Pedagogia do Oprimido, a partir da página 86.
} 
Quando se inventou a América, se nos tentou rotular com a índole de asiáticos, o já conhecido, mesmo que reprimido. Quando se viu que os índios daqui nada tinham a ver com os das Índias das especiarias orientais se buscou nos reconhecer como seu prolongamento.

A Europa tornou as outras culturas, mundos, pessoas em ob-jeto: lançado (-jacere) diante (ob-) de seus olhos. O "coberto" foi "des-coberto": ego cogito cogitatum, europeizado, mas imediatamente "en-coberto" como Outro. O outro constituído como o Si-mesmo. O ego moderno "nasce" nessa autoconstituição perante as outras regiões dominadas. ${ }^{36}$

Em realidade, não somos o europeu, estamos encobertos, somos a exterioridade negada nesse todo de opressão. Não somos nem ocidente nem oriente, apesar de já termos sido identificados como um e enraizados no outro. Por isso, então, que proponho um novo lugar para o nosso pensamento, o pensamento latino-americano: o Inocidente. In-ocidente que não é o ocidente apesar de em parte sê-lo; não, também, o oriente, o contraponto fechado ao ocidente. Estamos para além, diacrônica e diatopicamente, da totalidade; estamos na Transmodernidade.

Colonizados e conquistados, agora, rumamos, ou assim deve ser, para a libertação. Entendida como processo de síntese cultural, conforme uma anterioridade antropológica e material, apresenta-se-nos como fundante de acordo com a pedagógica libertadora. Nessa escolha ética, subsumimos a totalidade e, anadia-leticamente, redargüimos o processo histórico com a criticidade de nossas cachimônias.

A pedagógica é essencial por ser, como já dito, a convergência da erótica com a política. A metodologia da libertação, cremos, parte dela. Gritamos, agora, para sermos ouvidos; ouvimos, ainda, aqueles que tornitroam em seus lamentos. A cultura, desde já, torna-se a grande chave desse trajeto, o qual já viu esgotadas todas as tentativas da modernidade central e de sua crítica, ainda dentro da totalidade de centro, a pós-modernidade, para a consecução de uma sociedade realmente plural e justa.

O Outro negado de Dussel é, nesse contexto, o oprimido que cita Freire. Certo é que Paulo Freire buscou sempre sua práxis dentro de seu país, apesar dos exílios que a vida lhe forçou, mas é inconteste que o oprimido é o outro, a América

${ }^{36}$ DUSSEL, E. 1492: o encobrimento do Outro, p. 36. 
Latina, mesmo porque o Brasil também é latino-americano, apesar de muitas vezes o esquecermos, esquecimento ideológico que faz-nos mundos tão separados.

A anterioridade antropológica de Dussel intertextualiza-se cabalmente com a busca pela humanização da pedagogia empreendida por Freire. O ouvir o outro nada mais é que o apelo pelo diálogo; a analética é a saída que promana do oprimido. Paulo Freire vai nos falar da educação como prática de dominação como a imperante na hodiernidade, é a necrofilia; Dussel vai nos apresentar o filicídio cometido pelo pai-Estado que, ao mesmo tempo, reprime machistamente a mãecultura popular. Em sendo a mãe libertada, sê-lo-á o filho também e, por conseguinte, o pai, ou seja, cultura popular e Estado ligados para receberem, anadia-leticamente, o novo, o criador, a criança.

Analisando o fenômeno da dependência latino-americana, Paulo Freire diria que nosso continente estava às portas da revolução quando frustrada pelos vários golpes militares que assolaram a América Latina a partir de meados do século 20 . $\mathrm{Na}$ relação infra-superestrutura vê-se dos primeiros níveis de consciência da América Latina, qual seja, a cultura do silêncio. Desvela-se na relação colôniametrópole, relação de dependência. Daí o dualismo da sociedade dependente. A voz é o eco da voz metropolitana. Quando surgem os governos populistas, há a contradição de se romper com o silêncio ou aprofundá-lo. São sociedades fechadas desde o "descobrimento". Com o populismo, há manipulação, mas início de uma visualização de tal manipulação levada a cabo pelas elites nacionais. Começa-se a dinamizar a consciência, mais exigente, mudando-se as artes e o estilo político, num clima de pré-revolução. Para interceptá-lo, um golpe militar de Estado, o que exige nova estruturação do processo de transição. ${ }^{37}$

Então, desde antes, a filosofia latino-americana se torna uma pedagógica da libertação. É a relação mestre-discípulo em que se depreende o ouvir-o-outro e interpretá-lo. É uma pedagógica analética da libertação. O filósofo tem de se comprometer com a libertação do outro, por conseguinte, também a sua. Não é a filosofia mais um contemplar (lembrar da tese 11 de Marx), mas um amar. Nasce, então, a filosofia latino-americana, por um povo dominado, uma exterioridade. É um grito, um clamor! É analogicamente semelhante e distinta. É um novo momento da

\footnotetext{
${ }^{37}$ FREIRE, P. Conscientização, p. 63 e seguintes.
} 
filosofia, que ultrapassa o não-ouvir da Europa e busca-se como bárbara ao império. É a busca da alteridade com os povos do Terceiro Mundo. ${ }^{38}$

\section{5. À GUISA DE INCONCLUSÃO OU DIREITO, UMA CIÊNCIA INSTRUMENTAL}

A libertação tem de caminhar. Transitar. Não se a fará, efetivamente, se a estrutura engessante da sociedade atual prosperar. O mote nevrálgico da pedagogia coeva, segundo Luis Alberto Warat, é o fato de que "ela deve ensinar-nos a evitar a irreversibilidade da sociedade dos zumbis mal alimentados e mal-amados, solitários e doentes". 39

Toda a pedagógica demonstrada acima, como uma práxis da libertação cai por terra quando defrontada com a situação atual do direito. Entendemos ser o direito um instrumento de opressão que já em seu conteúdo, e salutarmente neste, se denota como tal. Não obstante, a relação pedagógica na esfera jurídica angaria os mesmos ares de opressão. Invariavelmente, a sala de aula é um palco em que o professor é o protagonista e os alunos os, nada além de, expectadores. O conhecimento não é construído, é dado, e por isso facilmente perdido. E é por isso, ainda, que a consciência crítica está a anos-luz de seus prosélitos.

Mesmo entendendo que o direito é, em última análise, ferramenta a ser usada, não podemos desprezá-lo. A partir dele, também, devirá a saída contrahegemônica, que Gramsci já vislumbrara como método. Entendemos como bom aporte teórico para a transição da libertação, alguns conceitos e análises estruturados por Gramsci, o mais latino-americano dos autores da totalidade européia. A guerra de posições colimada com a de movimento, numa escolha estratégica de uso; o bloco histórico; a concepção de Estado ampliado, entre outras. $^{40} \mathrm{O}$ direito, assim, também deve ter seu quinhão na libertação e por dentro ser tomado para a sua persecução.

Bom início seria carnavalizar o ensino do direito, uma pedagógica que desse espaço ao negado nas aulas coimbrãs dos juristas que parecem muito pouco entender da pedagógica, parecendo, até, estar avessos a ela. "Somos auto-

\footnotetext{
38 DUSSEL, E. Método para uma filosofia da libertação, p. 209 e seguintes.

${ }^{39}$ WARAT, Luis Alberto. Manifesto do Surrealismo Jurídico, p. 54.

${ }^{40}$ Ver interessante artigo COUTINHO, Carlos Nelson. As categorias de Gramsci e a realidade brasileira.
} 
suficientes", provavelmente dirão. Isso influi diretamente no ensino-aprendizagem. Dussel diria:

estes "sistemas" que se auto-alimentam, se auto-regulam e impedem que um leigo estranho julgue seus resultados (como um não-mestre pode ser tribunal de um concurso no magistério?, como um não-médico pode criticar o exercício da medicina?, como um nãoadvogado se atreveria a emitir um juízo sobre um caso penal?), se arrogam dentro de uma liturgia sagrada e altamente sofisticada o direito exclusivo de educar os que ingressam na sociedade política e mantê-los dentro de sua função em vida assegurada. ${ }^{41}$

Parece que, com este corte metodológico, podemos ficar tranqüilos ao ter falado tanto de pedagogia e filosofia, já que somos do direito e, à primeira vista, não teríamos legitimidade para dar pitacos nessas "áreas tão diversas da nossa", mesmo quando alguém vem e pretende dar aula sem nunca ter conhecido um plano de ensino ou que se eleva como doutrinador sem nunca ter freqüentado as carteiras dos filósofos. Ficamos com Warat que assim se manifesta: "precisamos também tentar uma pedagogia do absurdo (...). Estou farto do ensino tradicional. Sua linguagem instituída nos coloca na pior das prisões". 42

Para a nossa libertação - agora me refiro aos jusdiscentes - é preciso nossa conscientização e para ela se concretizar é indispensável que encontremos os temas geradores de nossa própria opressão, que desde logo começa a nos enforcar nas gravatas e nos eternos ternos de cores comedidas que usamos sob os sóis dos trópicos e subtrópicos latino-americanos. "O homem sempre percebe o novo desde o velho. A percepção moral do novo talvez seja uma utopia, porém o valor pedagógico de uma ilusão está na sua capacidade de nos mostrar o limite de nossos mergulhos". ${ }^{43}$ Quiçá o devaneio estudantil não nos leve mais longe? Ou então o ilusionismo não nos mostre a subliminaridade que a razão esconde em sua ideologia?

\footnotetext{
${ }^{41}$ DUSSEL, E. Para uma ética da libertação latino-americana: III - erótica e pedagógica, p. 204.

42 WARAT, L. A. A ciência jurídica e seus dois maridos, p. 48-49.

${ }^{43}$ WARAT, L. A. Idem, p. 155.
} 


\section{REFERÊNCIAS BIBLIOGRÁFICAS}

COUTINHO, Carlos Nelson. As categorias de Gramsci e a realidade brasileira. IN: NOGUERIA, Marco Aurélio. Gramsci e a América Latina. 2 ed. Rio de Janeiro: Paz e Terra, 1993.

DUSSEL, Enrique. Filosofia da Libertação na América Latina. Tradução de Luiz João Gaio. São Paulo: Loyola, s.d.

Método para uma filosofia da libertação: superação analética da dialética hegeliana. Tradução de Jandir João Zanotelli. São Paulo: Loyola, 1986.

Para uma ética da libertação latino-americana: III - erótica e pedagógica. Tradução de Luiz João Gaio. São Paulo: Loyola, s. d.

1492: o encobrimento do Outro: a origem do mito da modernidade: Conferências de Frankfurt. Tradução de Jaime A. Clasen. Petrópolis: Vozes, 1993.

FREIRE, Paulo. A importância do ato de ler: em três artigos que se completam. 18 ed. São Paulo: Cortez, 1987.

Conscientização: teoria e prática da libertação: uma introdução ao pensamento de Paulo Freire. 3 ed. São Paulo: Moraes, 1980.

Pedagogia da Autonomia: saberes necessários à prática educativa. 11 ed. Rio de Janeiro: Paz e Terra, 1999.

Pedagogia do Oprimido. 39 ed. Rio de Janeiro: Paz e Terra, 2004.

FREYRE, Gilberto. Além do apenas moderno: sugestões em torno de possíveis futuros do homem, em geral, e do homem brasileiro, em particular. 2 ed. Rio de Janeiro: Topbooks, 2001.

LUDWIG, Celso. A alternatividade jurídica na perspectiva da libertação uma leitura a partir da filosofia da libertação de Enrique Dussel. Dissertação de Mestrado. UFPR: Curitiba, 1993.

Da Ética à Filosofia Política Crítica na Transmodernidade: reflexões desde a Filosofia de Enrique Dussel. IN: FONSECA, Ricardo Marcelo (org.). Repensando a Teoria Geral do Estado. Belo Horizonte: Fórum, 2004.

MANCE, Euclides André. Uma introdução conceitual às filosofias de libertação. IN: Revista Libertação-Liberación. Curitiba: IFiL, ano I, № 1, 2000, p. 25-80.

MARX, Karl. Teses contra Feuerbach. IN: Coleção Os Pensadores. Tradução de José Arthur Giannotti. 2 ed. São Paulo: Abril Cultural, 1978.

OLIVEIRA, Rosa Maria Rodrigues de. Ética da Libertação em Enrique Dussel. IN: WOLKMER, Antonio Carlos (org.). Direitos Humanos e Filosofia Jurídica na América. Rio de Janeiro: Lumen Juris, 2004.

PAIVA, Vanilda. Do "problema nacional" às classes sociais. IN: Revista Educação e Sociedade. São Paulo: Cortez e Moraes, ano I, no 3, maio de 1979, p. 5-14.

SÁNCHEZ RUBIO, David. Filosofia, derecho y liberación en América Latina. Bilbao: Disclée, 1999.

WARAT, Luis Alberto. A Ciência Jurídica e seus dois maridos. Santa Cruz do Sul: Faculdades Integradas de Santa Cruz do Sul, 1985.

Manifesto do Surrealismo Jurídico. São Paulo: Acadêmica, 1988. 